\title{
Morphological aspects of fruits, seeds, and seedlings, and anatomy of seedlings of apuleia molaris spruce ex benth ${ }^{1}$
}

\author{
Alisson Rodrigo Souza Reis ${ }^{2 *}$, Alessandra Doce Dias de Freitas ${ }^{2}$, \\ Noemi Vianna Martins Leão ${ }^{3}$, Benedito Gomes dos Santos Filho ${ }^{4}$
}

\begin{abstract}
Apuleia molaris spruce ex benth, commonly known in Brazil as "amarelão," is a fast-growing forest plant with a potential for use in reforestation; however, there is little information about the physiology and morphology of its fruits, seeds, and seedlings. Thus, the objective of this work was to describe the morphology of the fruits, seeds, and seedlings, in addition to the anatomic patterns of seedlings, as a contribution to the technical-scientific knowledge and production of amazonian species for reforestation in the state of Pará. For this purpose, the morphological descriptions followed the parameters from specialized literature and the common techniques used in plant anatomy. The species presents leguminous fruit; seeds with pleurogram, average dimensions of 51.21, 21.33, and $2.09 \mathrm{~mm}$ length, width, and thickness, respectively; and seedlings with eophyll and pinnate metaphylls, cordiform, phanerocotylar germination, epigaeous, and foliaceous. Eophylls and metaphylls present uniseriate epidermis, collateral and dorsiventral vascular bundle. The morphological characteristics may help in field identification and in the identification of young plants, aiding the production of seedlings of this species. Furthermore, anatomically, the hypocotyl has no striking differences from the root.
\end{abstract}

Index terms: taxonomic identification, seedling production, seed technology.

\section{Aspectos morfológicos de frutos, sementes e morfo-anatômico de plântulas de apuleia molaris spruce ex benth.}

\begin{abstract}
RESUMO - O amarelão (Apuleia molaris Spruce ex Benth.) é uma essência florestal de rápido crescimento, com potencial para o reflorestamento, entretanto existem poucas informações a respeito da tecnologia e morfologia dos frutos, sementes e plântulas. Com isso, o objetivo do presente trabalho foi descrever a morfologia de frutos, sementes e plântulas, além dos padrões anatômicos das plântulas, como contribuição para o conhecimento técnico-científico e produção de espécies amazônicas para o reflorestamento no Estado do Pará. Para isso, as descrições morfológicas seguiram os parâmetros de literatura especializada e as informações anatômicas técnicas usuais em anatomia vegetal. A espécie apresenta frutos do tipo legume, semente com pleurograma, as sementes possuem dimensões médias de 51,21; 21,33; $2,09 \mathrm{~mm}$ para comprimento, largura e espessura respectivamente, e as plântulas com eofilos e metafilos imparipenados, cordiforme, germinação fânero cotiledonar, epigea, foliácea. Os eofilos e metafilos apresentam epiderme unisseriada, feixe vascular colateral e dorsiventral. As características morfológicas podem auxiliar na identificação em campo, e na identificação de plantas jovens, auxiliando a produção de mudas da referida espécie, anatomicamente o hipocótilo não apresenta diferenças marcantes da raiz.
\end{abstract}

Termos para indexação: identificação taxonômica, produção de mudas, tecnologia de sementes.

\section{Introduction}

Knowledge of the morphology of fruits, seeds, and seedlings is important because it provides information for plant germination, storage, quality, management, and all other areas that require a clear definition of morphological

${ }^{1}$ Submitted on 01/16/2016. Accepted for publication on 05/24/2016.

${ }^{2}$ Universidade Federal do Pará, Faculdade de Engenharia Florestal, 68372000 - Altamira, PA, Brasil.

${ }^{3}$ Embrapa Amazônia Oriental, Laboratório de Sementes Florestais, Caixa characters (Gunn, 1972; Lima, 1985; Barroso et al., 1999; Ramos; Ferraz, 2008). According to Bravato (1974), seed characteristics can be used for identification at the species level, as these characteristics are not much influenced by the environment.

Owing to the high diversity of the Amazon region,

Postal 48, 66095-100- Belém, PA, Brasil.

${ }^{4}$ Universidade Federal Rural da Amazônia, Instituto de Ciências Agrárias, 66077-830 - Belém, Pará, Brasil.

*Corresponding author <alissonreis@ufpa.br> 
coupled with the large number of Leguminosae species, there is a wide variety of morphological characteristics of fruits, seeds, and seedlings. Therefore, several authors have been trying to botanically organize and systematize the fruits, seeds, and seedlings of the family, emphasizing the work of Oliveira (1999), Garwood (1996), and Barroso et al. (1999).

This family has been the object of intense, constant systematization because of the large number of specimens and the difficult definitions in different classification systems, such as those by Cronquist (1968), Engler (1892), Takhtajan (1969), and the broad review of Lewis et al. (2005), among others. Advances in genetic analysis technologies have promoted the use of a new classification system, which has not yet been clearly defined nor has unanimous acceptance by specialists in the area, since it joins together monophyletic and paraphyletic groups; however, this form of grouping defines a new system without considering the morphological characteristics that have been used until the present date. Another issue is that there is no consensus regarding the systematic division of the family.

Lewis et al. (2005) suggested that the family has approximately 727 genera and 19,325 species, making it the third largest family of angiosperms, and divided it into three subfamilies: Caesalpinioideae, Mimosoideae, and Papilionoideae.

Since the 1980s, representatives of the family have been subjected to morphological descriptions of their fruits, seeds, and seedlings by Melo and Varela (2006), Matheus and Lopes (2007), Amorim et al. (2008), Silva et al. (2008), Ramos and Ferraz (2008), Lopes and Matheus (2008), Félix-da-Silva et al. (2009), Nogueira et al. (2010), Battilani et al. (2011), Rego et al. (2011), Barreto and Ferreira (2011), Rodrigues et al. (2012, 2014), Abreu et al. (2012), Gurgel et al. (2012, 2014), Alves et al. (2013), Rodrigues (2013), Braga et al. (2013), Feitosa (2014), Hartmann and Rodrigues (2014), Lobo et al. (2014), Oliveira (2014), Ribeiro et al. (2015), Ferreira and Barreto (2015) and Silva et al. (2015), with the aim of contributing to the scientific knowledge of Brazilian flora.

The genus Apuleia Mart. was described by Martius, and it has six confirmed species, characterized by pinnately compound, alternate leaflets; terminal corymb inflorescence; and flattened, oblique, oval, or oblong, and undeiscent elliptical leguminous fruit, occurring in Amazonian countries such as Venezuela, Uruguay, Argentina, and Brazil (Record and Hess, 1943).

In the Amazon region, the species under study is difficult to distinguish from similar taxa, being very similar to Apuleia leiocarpa (Vogel) J. F. Macbr. Rizzini (1971) considered it a variety, whereas Record and Hess (1943), upon describing the anatomical structure of the wood, noted that the variations are small and inconsistent.
Considering the dubious identification of the species, it is necessary to use other aspects such as the morphology of fruits, seeds, and seedlings, as well as anatomical characteristics, to distinguish and identify it. Thus, the objective of this study was to describe the morphological characteristics of the fruits, seeds, and seedlings, in addition to the anatomical aspects, as a contribution to the technical scientific knowledge necessary for the identification of Apuleia molaris Spruce ex Benth. seedlings.

\section{Material and Methods}

Seeds of amarelão (Apuleia molaris Spruce ex Benth.) were harvested from three selected trees in the municipality of Tucuruí, PA, and sent to the Laboratory of Forest Seeds of Embrapa Amazônia Oriental, in Belém, PA, Brazil, for laboratory tests.

Biometric measurements for length, width, and thickness were performed on 150 random fruits and seeds with the aid of a digital caliper.

To describe the phases of post-seminal development, 100 seeds were scarified with wood grit-80 sandpaper, germinated between moistened paper towels, in accordance with Brasil (2009), and maintained in a germinator at $25{ }^{\circ} \mathrm{C}$ and 12-hour photoperiod. Descriptions of the seedlings were carried out daily in sequential phases of development, recording the development of the primary root, the emergence of secondary roots, the beginning of the growth of the eophyll, the conspicuous apical bud, and the expansion of eophylls and metaphylls. Seedlings were considered as such from the phase of the protrusion of the root until the total formation of eophylls, and young plants from the appearance of the metaphyll (Ducke and Polhill, 1981). Seedlings that were more vigorous and that presented a normal primary root, hypocotyl, cotyledons, and metaphylls were described. For the morphological descriptions of fruits, seeds, and seedlings, the terminologies of Rizzini (1977) and Barroso et al. (1999) were used.

The anatomical study of eophylls and metaphylls was undertaken by dividing the leaf blade into the apex, middle, and base, and sections of the midrib, intermediate portion, and margin were carried out for each of these regions. For the present study, only the medial region was considered. The hypocotyl and roots were sectioned in the middle third.

Specimens were fixed in formaldehyde $/ 70 \%$ ethyl alcohol/glacial acetic acid (FAA70; Johansen, 1940), and stored in $70 \%$ ethyl alcohol to be used in the various histological studies (Johansen, 1940). After the mounting and storage/conservation in ethyl alcohol $70 \%$, the samples fixed in FAA70 were dehydrated in a butyl, tert-butyl alcohol series 
(Johansen, 1940) and embedded in histology paraffin.

The cross- and longitudinal-sections (7-15- $\mu \mathrm{m}$ thick) were carried out in a semi-automatic Leica RM 2245 rotary microtome, stained in safranin and astra blue (Gerlach, 1969) and toluidine blue (O'Brien et al., 1964). The permanent slides were mounted in Permount synthetic resin and the semi-permanent ones in glycerin gelatin (Kaiser, 1880). The terminology of Corner (1951, 1976), Esau (1974), Fanh (1974), and Barroso et al. (1999) was adopted.

The diaphanization of fully developed metaphylls was carried out by immersing them, whole and sectioned, in a solution of $20 \%$ sodium hydroxide (Arnott, 1959) until depigmentation, and then washing in distilled water. The samples were stained with 1\% hydro-alcohol safranin (Johansen, 1940), for 24 hours. After staining, the material was dehydrated in an increasing ethanol and aceto-butyl series (Kraus and Arduin, 1997), and mounted between 2 $\mathrm{mm}$ thick glass plates in Canada balsam.

Small portions of the terminations of vascular elements were mounted between a slide and coverslip and placed in synthetic resin. The descriptions of the venation pattern followed the classification of Hickey (1973).

Photomicrographs were obtained through a Zeiss Axiolab microscope, using several objectives, with an attached Canon Powershot A 640 digital camera, using Canon Digital Camera Solution Disk v29 software. Image processing was performed with Adobe Photoshop CS version 8.0.1., and the scales were made with the aid of a micrometered slide in the different amplifications.

\section{Results and Discussion}

Fruits dry legume type, indehiscent, ellipsoid, coriaceous, polyspermic, with monocarpellary gynoecium, dark beige to black color, with velvety indumentum, containing on average four seeds per fruit (Figure 1), coriaceous pericarp, externally dark brown and beige internally, apex acuminate and attenuated. The measurements of length, width and weight have been split into five levels of frequency (Figure 2), the values found for the highest frequency level are close to the average as well as the mode values (Table 1), they have low relative standard deviation, which means that the sample and the biometric data of the fruits and seeds have been well accomplished. The data can be used in the species identification, a parameter which was also used by Silva et al. (2014). The type of fruit is a diagnostic feature of the Leguminosae, according to Barroso et al. (1999), Lopes et al. (2012), Ojeda et al. (2013), Albuquerque et al. (2015), and the classic studies in morphology.

Barroso et al. (1999) classified the genus Apuleia as samaroid-type legume, dry undeiscent, flat and compressed, adapted to anemochorous seed dispersal with one to a few seeds, oblique, slightly coriaceous, with sparing-spongy mesocarp. Thus, the fruits of the family present many forms, as observed by Barroso et al. (1999), Silva et al. (2015), Ojeta (2013), and Silva et al. (2015).

Seeds ellipsoid, bitegmic, light beige testa, small circular hilum, fugacious funiculus, barely noticeable pleurogram bordering all seeds (Figure 1E), hilum in a circular to elliptical depression, small and dark-colored, micropyle and raphe inconspicuous, prominent chalaza at apex and characterized by a darker stripe surrounding seed. Embryo basal, linear, occupying less than one-third of the seed. Primary taproot (Figures 3 and 4) circular, whitish, becoming light beige when the plant is young (Figure $3 \mathrm{~F}$ ), thinning in the distal portion.
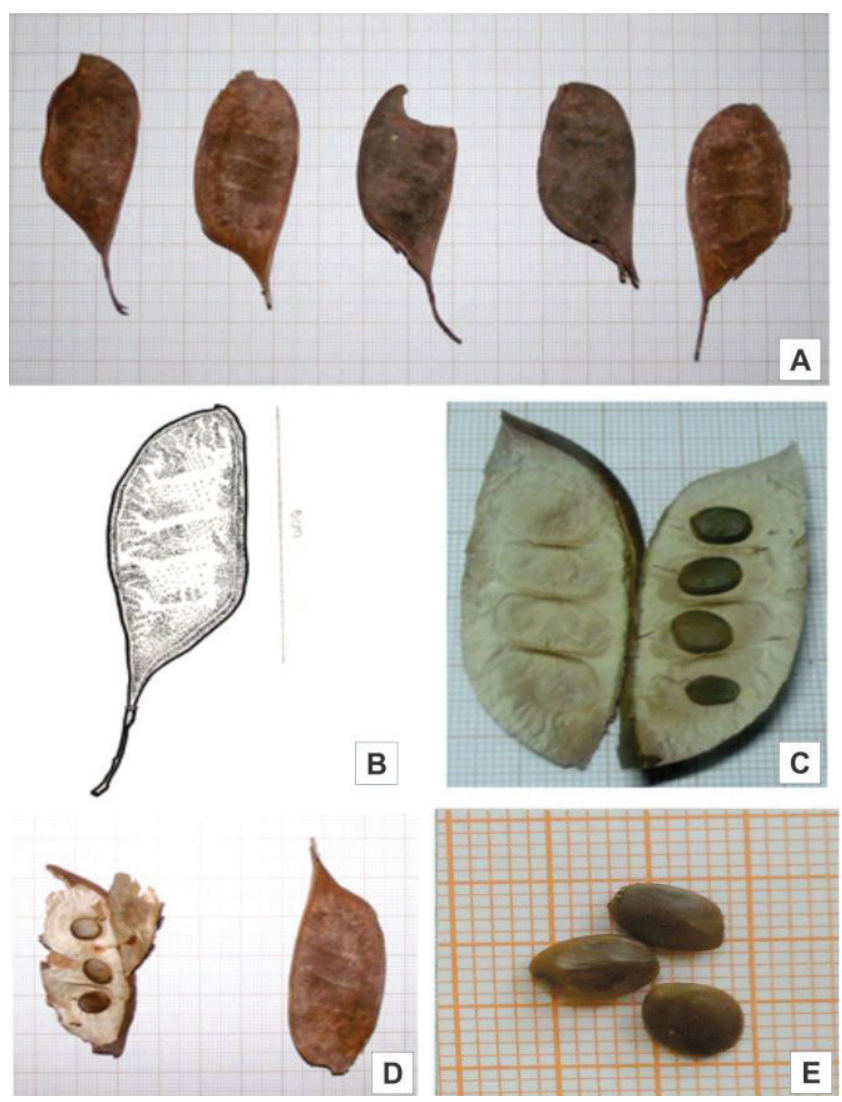

Figure 1. View the result of Amarelão (Apuleia moralis Spruce ex Benth.) . A - heteromorphism make fruit; B - Schematic drawing of the fruit; C - Four fruit with seeds; D - Fruit seeds with three; E - Seed view. 


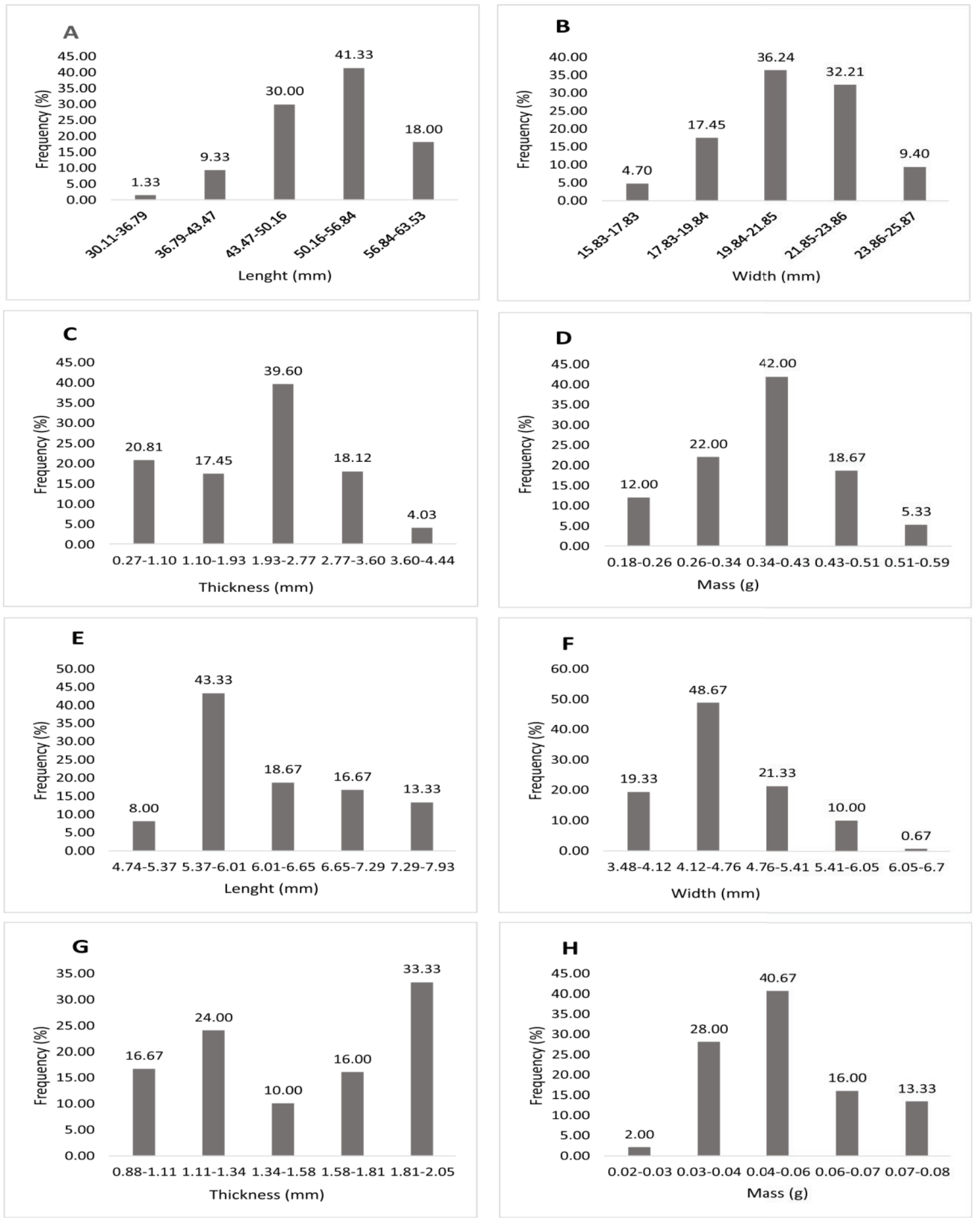

Figure 2. Frequency of distribution of length (A), width (B), thickness (C) and mass (D) of fruits and length (E), width (F), thickness $(\mathrm{G})$ and mass $(\mathrm{H})$ seed of Apuleia moralis Spruce ex Benth. 
Table1. Biometric data of fruits and seeds of Apuleia molaris Spruce ex Benth.

\begin{tabular}{ccccccccc}
\hline & \multicolumn{2}{c}{ Length $(\mathrm{mm})$} & \multicolumn{2}{c}{ Width $(\mathrm{mm})$} & \multicolumn{2}{c}{ Thickness $(\mathrm{mm})$} & \multicolumn{2}{c}{ Weight $(\mathrm{g})$} \\
\cline { 2 - 8 } & Fruit & Seeds & Fruit & Seeds & Fruit & Seeds & Fruit & Seeds \\
\hline Average & 51.21 & 6.22 & 21.33 & 4.59 & 2.09 & 1.52 & 0.37 & 0.04 \\
Fashion & 49.31 & 6.01 & 23.3 & 4.07 & 0.48 & 1.91 & 0.37 & 0.04 \\
Deviation & 5.92 & 0.76 & 1.97 & 0.55 & 0.94 & 0.35 & 0.08 & 0.02 \\
\hline CV $(\%)$ & 8 & 12.31 & 9.27 & 11.98 & 45.25 & 23.46 & 23.15 & 24.97 \\
\hline
\end{tabular}
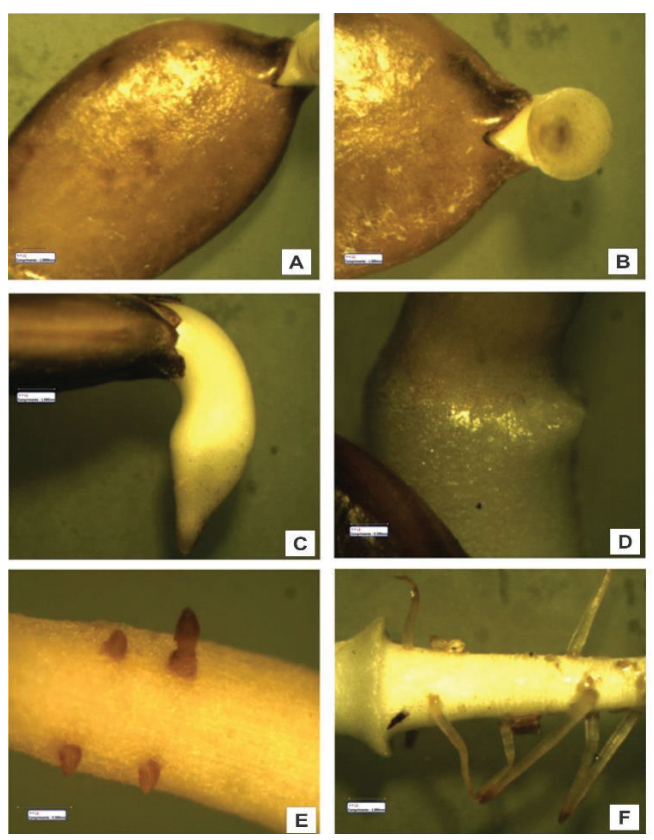

Figure 3. Phases of development of primary Amarelão root (Apuleia moralis Spruce ex Benth.): A - seed coat of Vista; B - View the darkened hood; C - Detail of neck region with the prominence; D - Emergence of secondary roots; E - Grafting of secondary roots.

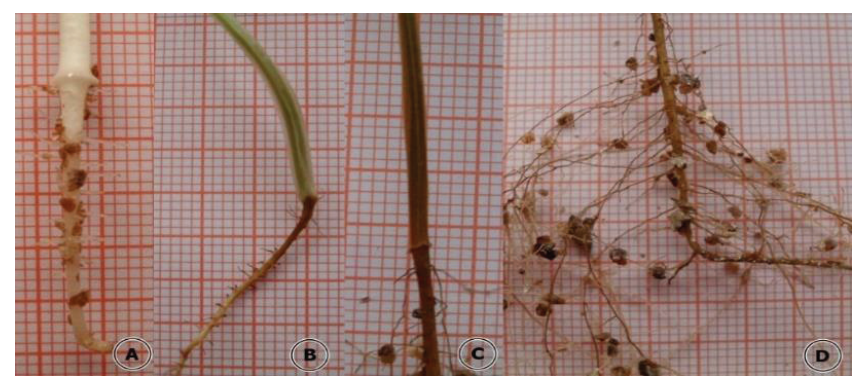

Figure 4. Root Vista at different stages of seedling development of Amarelão (Apuleia moralis Spruce ex Benth.): A - Details prominent whitish lap; B view of angular hypocotyl when ripe; $\mathrm{C}$ - Hypocotyl coloring change; D - Details of adventitious.
Cotyledons foliaceous, concave plane, parallel, elliptical, smooth, greenish, slender, with no apparent ribs, subchordate base, rounded apex, with entire edge invaginated (Figure 5) at hypocotyl-radicle axis insertion point; dark brown slender integument, dry, membranaceous, coated by very thin layer; abundant endosperm, peripheral, fleshy, and hyaline. According to Gunn (1981), who studied five tribes of the subfamily Caesalpinioideae, the endosperm was only present in $32 \%$ of the species studied, and it confers a hard consistency to the seed, causing the increase in size and the rupture of the testa, Hypocotyl-radicle axis straight, short, cylindrical, characteristics that have been found in Senna multijuga var. lindleyana by Amorin et al. (2008).
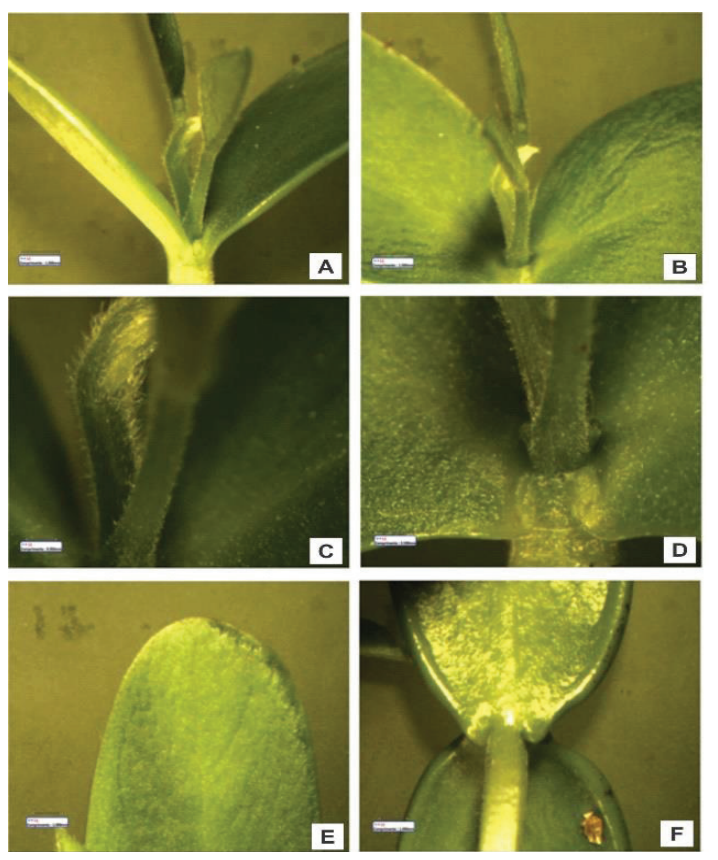

Figure 5. Eophylls insert View of seedling Amarelão (Apuleia moralis Spruce ex Benth.): A - opposite insertion of eophylls and the crossing of metaphylls; B - Detail of the apical bud; $\mathrm{C}$ - hairiness of the apical bud; D - insertion and hairiness of eophylls; E - apex mucronate the eophyll and sessile base corded. Bar A-B $=1.5 \mathrm{~mm}$; C-D $=0.5 \mathrm{~mm}$; E-F $=1 \mathrm{~mm}$. 
The size of the seeds is similar to that of Enterolobium schomburgkii Benth. analyzed by Ramos and Ferraz (2008) and Loureiro et al. (2013) studied Amburana cearensis (Fr. All.) a. C. Smith. The seeds of Leguminosae have various shapes and sizes, which makes it difficult to establish a standard for the family (Barroso et al., 1999).

Epicotyl cylindrical, greenish Cotyledons foliaceous, sessile, opposite, elliptical, with obtuse apex and base (Figure 5). Eophylls greenish, cordiform, angular, odd pinnate, unifoliated, apex mucronate, base cordate, with three leaflets. Metaphylls (Figure 6) follow same pattern as eophylls, with stipules present in each axillary bud. Seedlings phanero-epigeo-foliaceous type (figure 7).
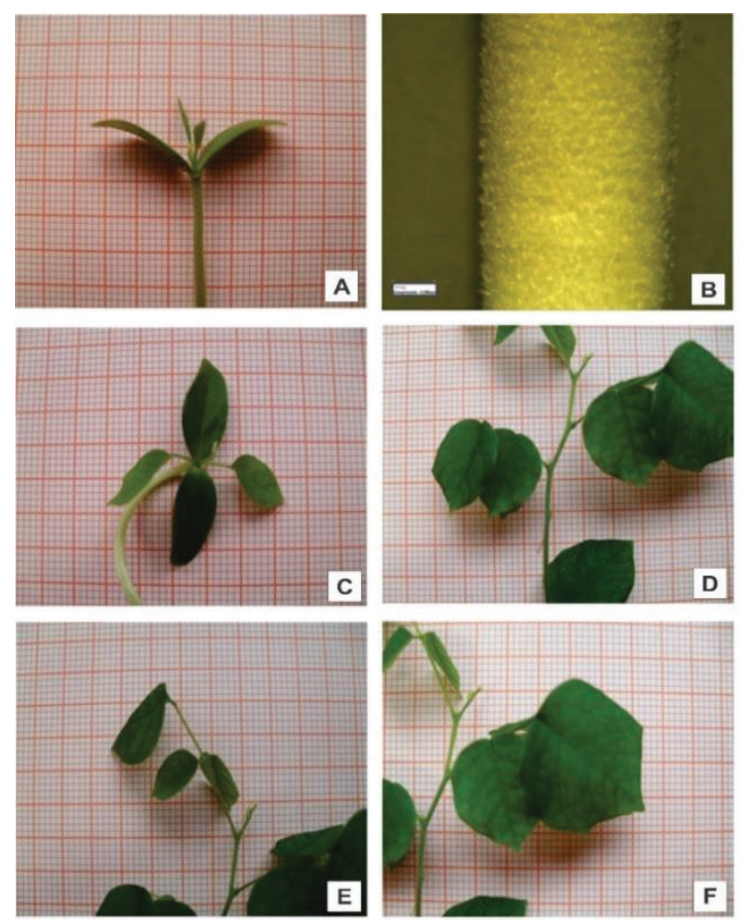

Figure 6. View of metaphylls of Amarelão (Apuleia moralis Spruce ex Benth.): A - immature metaphylls; B Pilosidade hypocotyl; C - mature metaphylls; D alternating phyllotaxy of metaphylls; $\mathrm{E}$ - composed trifoliate leaf; F - cordiforme shape metaphyll.

Hypocotyl greenish, cylindrical, becoming light beige, quadrangular when mature. Epidermis unicellular, heterodimensional, with thin epicuticular wax; anticline outer wall lightly papillose with filiform trichomes; lacunar collenchyma beneath epidermis (Figure 8); Root epidermis multicellular with thin wall and fiber bundles protecting cortex and amphicribal vascular bundle; root collar prominent and whitish (Figure 9) starch very frequently present in cortex cells; cortex medulla circular, with four poles, in which collateral vascular bundles and cambium located in various stages of development (Figure 9). According to Souza (2003) and Cutler (2007), there are few anatomical differences between the hypocotyl and the root in the early stages of plant development, as seen in this study, because both have the same anatomical structures. Nodules were not observed in the roots, an exception in this family known for nitrogen fixation associated with Rhizobium bacteria.
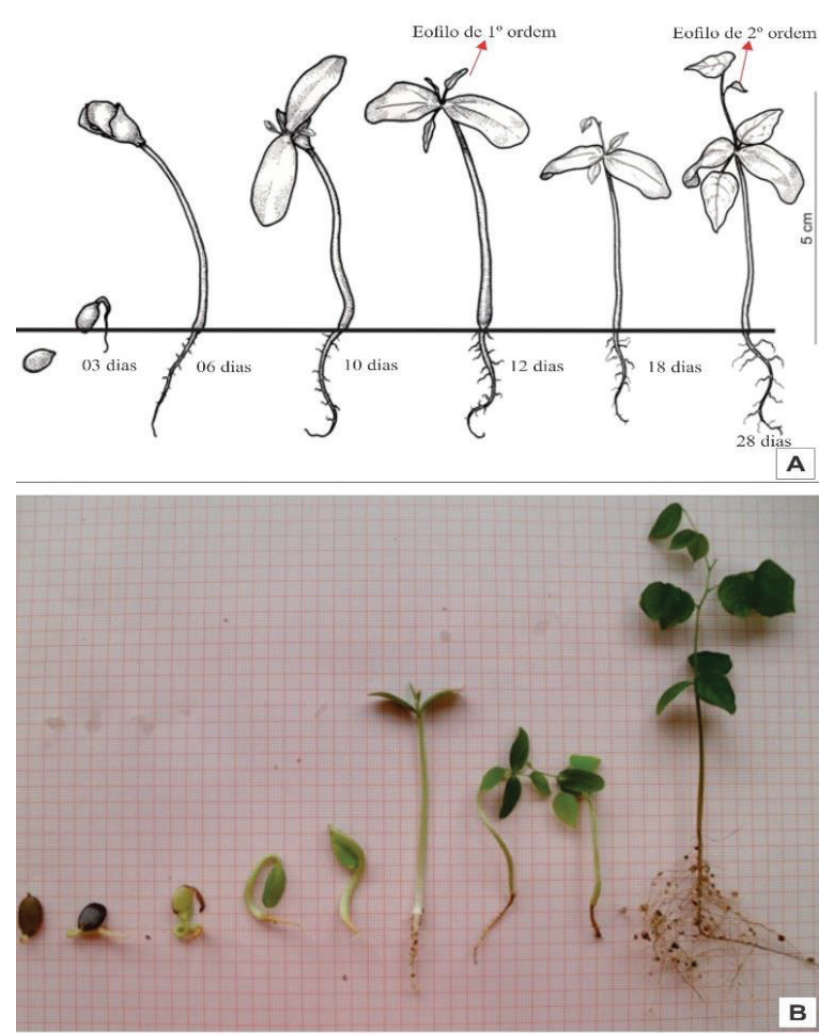

Figure 7. Amarelão of development stages (Apuleia moralis Spruce ex Benth.): A - schematic drawing; B Digital Photos.

Anatomically, eophylls and metaphylls do not present differences, being dorsiventral, hypostomatic, with unicellular epidermis, papillose, mesophyll with a layer of palisade parenchyma and four lacunary, collateral vascular bundles protected by bundles of fibers, cells papillose in abaxial epidermis (Figure 10). Moreira-Coneglian and Oliveira (2006), studying 10 species of the family, observed the same type of vascular bundle found in this species, in addition to observing that the cotyledons have differentiated lacunary and palisade parenchyma, and they also claim that the trend in structural complexity of the eophyll and metaphyll can be justified by the functions performed by these structures, and can be used as a taxonomic and phylogenetic characteristic. 

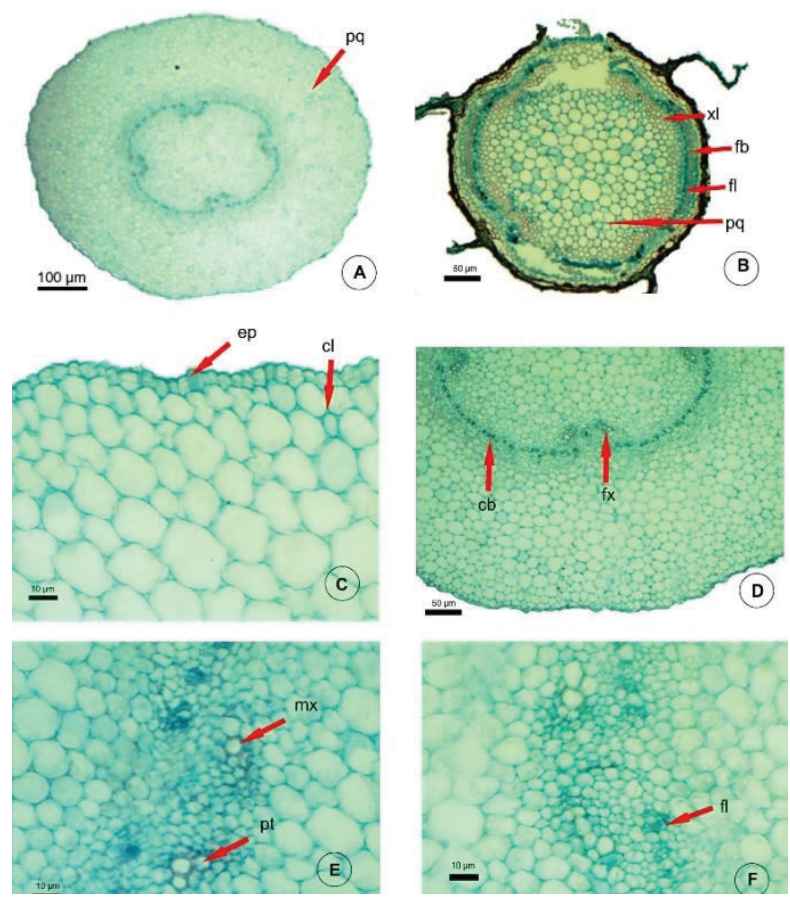

Figure 8. Anatomical hypocotyl view: A - general view, in the circular; B - view of mature hypocotyl formed with tissue; C - view of uniseriate epidermis; D - view the formation of the vascular cambium; E - view of protoxylem and metaxylem; Fview the phloem in training, pq - fundamental parenchyma, $\mathrm{xl}$ - primary xylem, pt - protoxylem, fl - phloem.

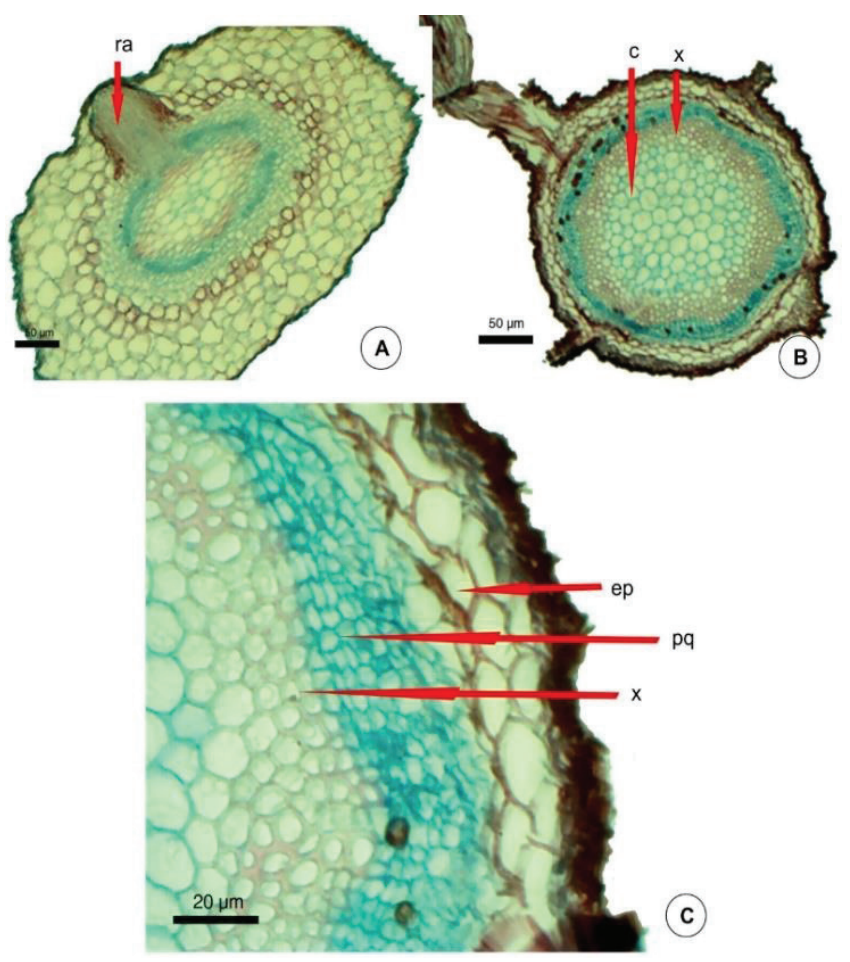

Figure 9. Anatomical root view: A - overview of the young root, when with the external color whitish, with formation of adventitious roots; B - view of mature root with the formation of adventitious roots; $\mathrm{C}$ - detailed view of plant tissues, and $\mathrm{p}$ - skin, cause fundamental parenchyma, c - cortex, $\mathrm{x}$ - xylem, ra-root. 
Glandular trichomes were observed, as well as a cuticle overlaying this epidermis, which, according to Esau (1974), is of interest because of the impermeabilization of the leaf surface hampering the absorption of mineral nutrients, fungicides, and herbicides. These characteristics determine the correct identification of the species in its natural environment, contributing to ecological studies of natural regeneration.

Leaf with reticulated nerving, brochidodromous venation, tapering toward base-apex; 5-6 pairs of alternate secondary veins, Secondary veins do not affect margin, being considered brochidodromous, tertiary veins moderately branched forming inconsistent, reticulated, irregular polygons. Quaternary veins dichotomized, ending without areolae with 3-6 arms (Figures 11 and 12). The pattern is another parameter that can be successfully used for identification of the species, this feature was used by Alvarez et al. (2001) to distinguish two species of Swartzia occurring in the restinga.

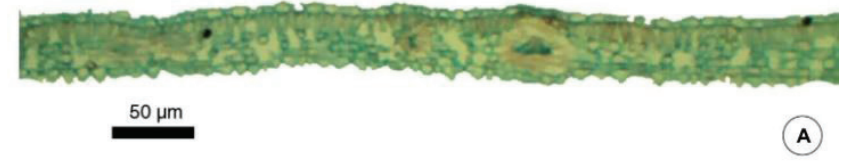

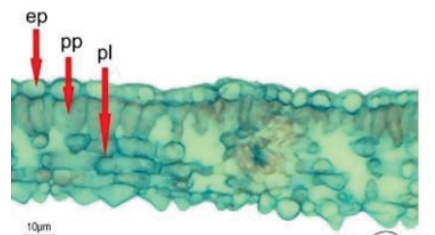

(B) $100 \mathrm{~m}$

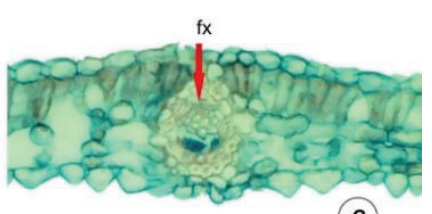

(c)

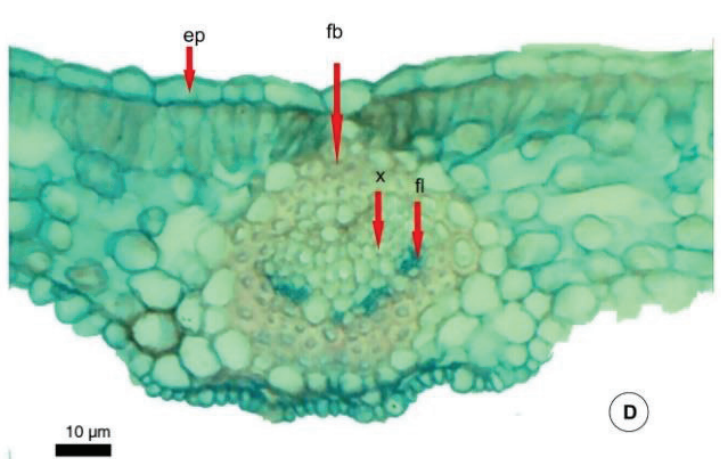

Figure 10. Anatomical view mesophyll: A - general view; B View of the parenchyma: $\mathrm{C}$ - view of the vascular bundle; $D$ - View from the midrib, with vascular tissue, ep - skin, pp - palisade, $\mathrm{pl}$ - spongy parenchyma, $\mathrm{fb}$ fiber, $\mathrm{fx}$ - vascular bundle, $\mathrm{x}$ - xylem, $\mathrm{fl}$ - phloem.
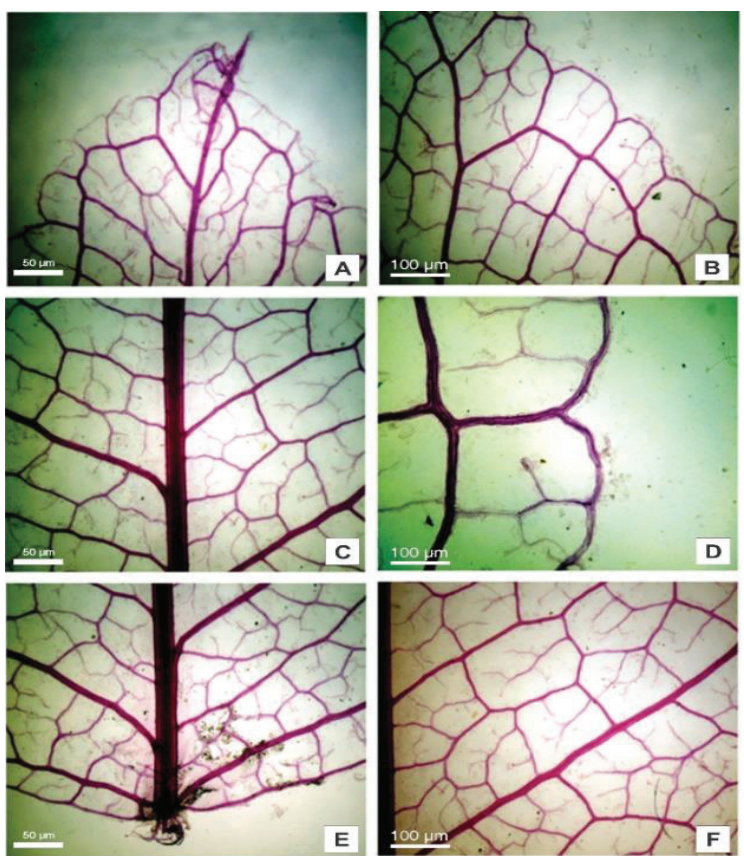

Figure 11. Anatomical view of venation Amarelão (Apuleia moralis Spruce ex Benth.): A - view from the summit; B - view from the shore; C - View from the middle region; D - View from the shore in the middle third region; E - view of the base; F - view of the secondary rib.
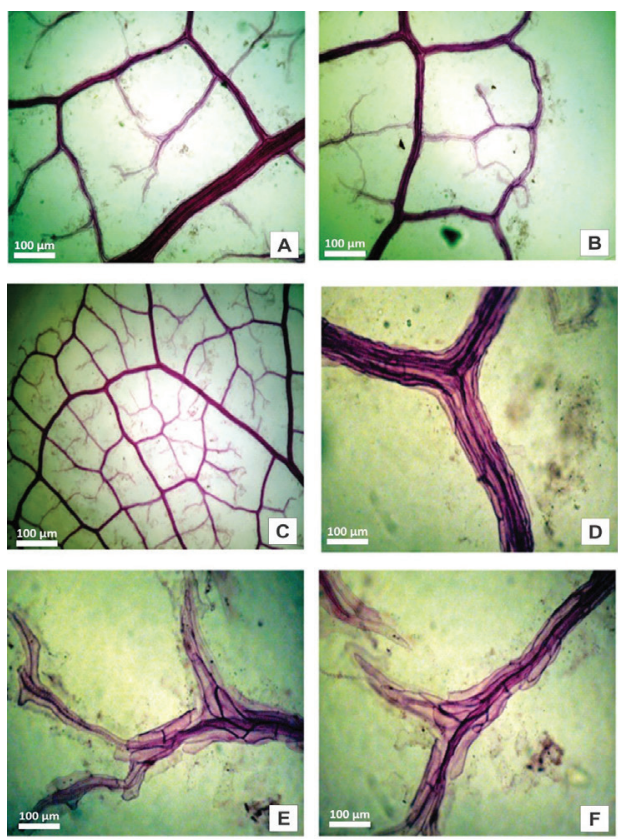

Figure 12. Anatomical view of venation Amarelão (Apuleia moralis Spruce ex Benth.): A - detail of the termination of the rib; B - Margin; C - View network of veins of the leaf blade; D - caliber vascular bundle; E - F - Detail of vascular elements. 


\section{Conclusions}

The species has peculiar morphological characteristics, such as the type of fruit and the pleurogram in seeds, which are typical of the family Fabaceae and allow them to be identified in the field.

There are no striking anatomical differences between the hypocotyl and the root.

The size and shape of the seed and the format and layout of eophylls and metaphylls allow identification of the species in the field.

\section{References}

ABREU, G. T.; LOPES, H. M.; ROSSETTO, C. A. V.; GERMANO FILHO, P.; SILVA, E. R. Características físicas e estrutura de sementes e morfologia de plântulas de Flemingia macrophylla (Willd.) Alston. Revista Brasileira de Sementes, v.34, n.3 p.658-664, 2012. http://www.scielo.br/pdf/rbs/v34n4/18.pdf.

ALBUQUERQUE, A. N.; ALBUQUERQUE, M. C. F.; MENDONÇA, E. A. F.; MARIANO, D. C.; OKUMURA, R. S.; COLETTI, A. J. Aspectos morfológicos de frutos, sementes e plântulas de sucupira preta. Revista de Ciências Agrárias, v.58, n.3, p.233-239, 2015. http://dx.doi.org/10.4322/rca.1720.

ALVAREZ, A. S.; POTIGUARA, R. C. V.; SANTOS, J. U. M. Arquitetura foliolar de Swartzia Brachyrachis Harms var. snethlageae (Ducke) Ducke e Swartzia laurifolia Bentham (Leguminosae-Papilionoideae), ocorrentes na restinga de Algodoal/Maiandeua-Pará. Boletim do Museu Paraense Emílio Goeldi. Série Botânica, v.17, n.1, 2001.

ALVES, M. C. J. L.; LIMA, P. B.; LIMA, L. F.; ZICKEL, C. S. Descrição morfológica para identificação das plântulas de nove espécies lenhosas de uma floresta de restinga. Biota Neotropica, v.13, n. 3, p. 374-383. 2013. http://www.scielo.br/pdf/bn/v13n3/1676-0603-bn-13-03-374.pdf

AMORIM, I. L.; DAVIDE, A. C.; FERREIRA, R. A.; CHAVES, M. M. F. Morfologia de frutos, sementes, plântulas e mudas de Senna multijuga var. lindleyana (Gardner) H. S. Irwin \& Barneby -Leguminosae Caesalpinioideae. Revista Brasileira de Botânica, v.31, n.3, p.507-516, 2008. http://www. scielo.br/pdf/rbb/v31n3/a14v31n3.pdf

ARNOTT, H.J. Leaf clearings. Turtox News, v.37, n.8, p.192-4. 1959.

BARRETO, S. S. B.; FERREIRA, R. A. Aspectos morfológicos de frutos, sementes, plântulas e mudas de Leguminosae Mimosoideae: Anadenanthera colubrina (Vellozo) Brenan e Enterolobium contortisiliquum (Vellozo) Morong. Revista Brasileira de Sementes, v.33, n.2 p.223-232, 2011. http:// www.scielo.br/pdf/rbs/v33n2/04.pdf

BARROSO, G. M.; MORIM, M. P.; PEIXOTO, A. L.; ICHASO, C. L. F. Frutos e Sementes: morfologia aplicada à sistemática de dicotiledôneas. 1.ed. Editora UFV, Viçosa, MG, 1999. 443p.

BATTILANI, J. L.; SANTIAGO, E. F.; DIAS, E. S. Morfologia de frutos, sementes, plântulas e plantas jovens de Guibourtia hymenifolia (Moric.) J. Leonard (Fabaceae). Revista Árvore, v.35, n.5, p.1089-1098, 2011. http:// www.scielo.br/pdf/rarv/v35n5/a15v35n5.pdf

BRAGA, L. F.; OLIVEIRA, A. C. C.; SOUSA, M, P. Morfometria de sementes e desenvolvimento pós-seminal de Schizolobium amazonicum Huber (Ducke) - Fabaceae Cientifica, v. 41, n. 1, p.1-10, 2013. http://dx.doi. org/10.15361/1984-5529.2013v41n1p01-10
BRAVATO, M. Estudio morfologico de frutos y semillas de las mimosoideae (Leguminosae) de Venezuela. Acta Botanica Venezuelica, v.5, p.317-361, 1974. http://www.scielo.org.ve/pdf/abv/v33n1/art04.pdf

CORNER, E. J. H. The leguminous seed. Phytomorphology, v.1, p. 117-150, 1951.

CORNER, E.J.H. The seeds of dicotyledons.v.1. University Press, Cambridge, 1976. $320 \mathrm{p}$.

CRONQUIST, A. The evolution and classification of the flowers plants. New York: Willian C. Steere, 1968. 366p.

DUCKE, J.A.; POLHILL, R.M. Seedlings of Leguminosae. In: POLHILL, R.M.; RAVEN, P.H. (eds.). Advances in legumes systematics. Royal Botanic Gardens, Kew Part 1, p. 941-949, 1981.

ENGLER, A.; PRANTL, K. In die Naturlichen Planzenfamilien. Leipzig: Wilhelm Engelmann, v.3, p. 138-178, 1892.

ESAU, K. Anatomia de plantas com sementes. São Paulo: Edgard Blücher, p. $312,1974$.

FANH, A. Anatomia Vegetal. 2 ed, Madri, H. Blume, p. 638, 1974.

FEITOSA, G. V.; SANTOS, J. U. M.; GURGEL, E. S. C.; OLIVEIRA, D. M. T. Morphology of fruits, seeds, seedlings and saplings of three species of Macrolobium Schreb. (Leguminosae, Caesalpinioideae) in the Brazilian Amazon floodplain. Acta Botaníca Brasílica, v.28, n.3, p.422-433, 2014. http://www.scielo.br/pdf/abb/v28n3/a16v28n3.pdf

FÉLIX-DA-SILVA, M. M.; BASTOS, M. N. C.; GURGEL, E. S. C. Aspectos taxonômicos e morfológicos do processo germinativo e da plântula de Peltogyne venosa subsp. Densiflora (Spruce ex Benth.) SILVA, M.F.(Leguminosae - Caesalpinioideae). Boletim do Museu Paraense Emílio Goeldi. Ciências Naturais, v.4, n.3, p.291-302, 2009. http://scielo.iec.pa.gov. br/pdf/bmpegcn/v4n3/v4n3a03.pdf.

FERREIRA, R. A.;BARRETTO, S. S. B. Caracterização morfológica de frutos, sementes, plântulas e Mudas de pau-brasil (Caesalpinia echinata Lamarck). Revista Árvore, v.39, n.3, p.505-512, 2015. http://www.scielo.br/ pdf/rarv/v39n3/0100-6762-rarv-39-03-0505.pdf

GARWOOD, N. C. Functional morphology of tropical tree seedlings. In: SWAINE, M. D. (ed.). The ecology of tropical forest tree seedlings. UNESCO/Parthenon Publishing. Paris,1996, p.59-129, 1996.

GERLACH, D. Botanische Mikrotechnik: Eine Einführung. Stuttgart: Georg, Thieme. 1969. 311p.

GUNN, C. R. Seeds of leguminosae. In: POLHILL, R. M.; RAVEN, P. H. Advances in legumes systematics. England Royal Botanic Garden Kew, v.2, p.913-925, 1981. http://www.scielo.br/scielo.php?script=sci nlinks\&ref $=000113 \&$ pid $=$ S0044-5967200400010000200013\&lng $=$ pt

GUNN, C.R. Seed collecting and identification. In: KOZLOWSKI, T.T. (ed.) Seed Biology, Academic Press, New York, v.3, 1972. 432 p.

GURGEL, E. S. C.; SANTOS, J. U. M.; LUCAS, F. C. A.; BASTOS, M. N. C. Morfologia de plântulas de Leguminosae e o potencial sistemático. Rodriguésia, v.63, n.1, p. 65-73, 2012. http://rodriguesia-seer.jbrj.gov.br/ index.php/rodriguesia/article/view/382/149.

GURGEL, E. S. C.; SILVA, M. F.; LUCAS, F. C. A.; CARREIRA, L. M. M.; SANTOS, J. U. M. dos. Morfologia do fruto e da semente de três espécies de Senna Mill. Leguminosae - Caesalpinioideae). Biota Amazônia, v.4, n.2, p.80-86, 2014. http://periodicos.unifap.br/index.php/biota/article/view/944/ v4n2p80-86.pdf 
HARTMANN, L. S.; RODRIGUES, R. S. Morfologia de plântulas de Martiodendron excelsum e sua relevância sistemática em Dialiinae (Leguminosae, “Caesalpinioideae”). Rodriguésia, v.65, n.3, p.577-586, 2014. http://rodriguesia-seer.jbrj.gov.br/index.php/rodriguesia/article/view/ID $\% 20$ 839/pdf_115.

HICKEY, L. J. Classification of the architecture of dicotyledonous leaves. American Journal of Botany, v.60, n.1, p.17-33 1973. http://www.u.arizona. edu/ bblonder/leaves/The_secrets_of_leaves/Making_skeletons_files/ American\%20Journa1\%20 of\%20Botany\%201973\%20Hickey\%20 Classification $\% 20$ of $\% 20$ the $\% 20$ architecture $\% 20$ of.pdf

JOHANSEN, D. A. Plant Microtechnique. Tata McGraw-Hill Book Company, Bombay. 2ed, 1940. 523 p.

KAISER, E. Verfahren zur Herstellung einer tadellosen Glycerin Gelatine. Bot Zentralb. 1880. 2526p.

KRAUS, J. E.; ARDUIN, M. Manual básico de métodos em morfologia vegetal. Rio de Janeiro: EDUR, 1997. 198 p.

LEWIS, G. P.; SCHRIRE, B.; MACKINDER, B.; LOCK, M. Legumes of the world. Royal Botanic Gardens, Kew, 2005. 577p.

LIMA, H. C. Diplotropis Benth. (Leguminosae Faboideae) - estudo dos táxons infragenéricos. Acta Amazonica, v.15, p.61-75. 1985. http://www. scielo.br/pdf/aa/v15n1-2/1809-4392-aa-15-1-2-0061.pdf

LOBO, G. A.; SANTANA, D. G.; SALOMÃO, A. N.; REHBEIN, L. S.; WIELEWICKI, A. P. A technological approach to the morphofunctional classification of seedlings of 50 Brazilian forest species. Journal of Seed Science, v.36, n.1, p.87-093, 2014. http://www.scielo.br/pdf/jss/v36n1/ a11v36n1.pdf

LOPES, A.; ROSA-OSMAN, S. M.; PIEDADE, M. T. F. Caracterização morfológica das plântulas de cinco Espécies arbóreas da floresta estacional Semidecidual, Brasil. Floresta, v. 42, n.1, p.105 - 114, 2012. http://dx.doi. org/10.5380/rf.v42i1.26306.

LOPES, J. C.; MATHEUS, M. T. Caracterização morfológica de sementes, plântulas e da germinação de Dimorphandra wilsonii Rizz. -faveiro-dewilson (Fabaceae caesalpinioideae). Revista Brasileira de Sementes, v.30, n.1, p.96-101, 2008. http://www.scielo.br/pdf/rbs/v30n1/a13v30n1.pdf

LOUREIRO, M. B.; TELES, C. A. S.; VIRGENS, I. O.; ARAÚJO, B. R. N.; FERNANDEZ, L. G.; CASTRO, R. D.. Aspectos morfoanatômicos e fisiológicos de sementes e plântulas de Amburana cearensis (fr. all.) a.c. smith (Leguminosae -Papilionoideae). Revista Árvore, v.37, n.4, p.679-689, 2013. http://www.scielo.br/pdf/rarv/v37n4/11.pdf

MATHEUS, M. T.; LOPES, J. C. Morfologia de frutos, sementes e plântulas e germinação de sementes de Erythrina variegata L. Revista Brasileira de Sementes, v. 29, n. 3, p.8-17, 2007. http://www.scielo.br/pdf/rbs/v29n3/ a02v29n3.pdf

MELO, M. F. F.; VARELA, V. P. Aspectos morfológicos de frutos, sementes, germinação e plântulasde duas espécies florestais da Amazônia. I. Dinizia excelsa Ducke (Angelim pedra). II Cedrelinga catenaeformis Ducke (cedrorana) - leguminosae: Mimosoideae. Revista Brasileira de Sementes, v.28, n. 1, p.54-62, 2006. http://www.scielo.br/pdf/rbs/v28n1/a08v28n1.pdf

MOREIRA-CONEGLIAN, I. R.; OLIVEIRA, D. M. T. Anatomia comparada dos limbos cotiledonares e eofilares de dez espécies de Caesalpinioideae (Fabaceae). Revista Brasileira de Botânica, v.29, n. 2, p. 193-207, 2006. http://www.scielo.br/pdf/rbb/v29n2/a01v29n2.pdf
NOGUEIRA, F. C. B.; FILHO, S. M.; GALLÃO, M. I. Caracterização da germinação e morfologia de frutos, sementes e plântulas de Dalbergia cearensis Ducke (pau-violeta) - Fabaceae. Acta Botânica Brasilica. v.24, n.4, p. 978-985, 2010. http://www.scielo.br/pdf/abb/v24n4/v24n4a13.pdf

O'BRIEN, T. P., N. FEDER, M. E. MCCULLY. Polychromatic staining of Plant cell walls by toluidine blue O. Protoplasma, 1964. http://citeseerx.ist. psu.edu/viewdoc/download?doi=10.1.1.556.7606\&rep=rep1\&type=pdf

OJEDA, F. S.; HOC, P. S.; GARCIA, M. T. A. Morphology of seeds and seedlings of four species of Vigna Savi (Leguminosae, Phaseolinae). Acta Botanica Brasilica, v.27, n. 3, p. 483-489, 2013. http://www.scielo.br/pdf/ abb/v27n3/v27n3a04.pdf

OLIVEIRA, D. M. T. Morfologia de plântulas e plantas jovens de 30 espécies arbóreas de Leguminosae. Acta Botanica Brasilica, v.13, n.3, p.263-269, 1999. http://www.scielo.br/pdf/abb/v13n3/v13n3a06.pdf

OLIVEIRA, J. H. G.; IWAZAKI, M. C.; OLIVEIRA, D. M. T. Morfologia das plântulas, anatomia e venação dos cotilédones e eofilos de três espécies de Mimosa (Fabaceae, Mimosoideae). Rodriguésia, v.65, n.3, p.777-789, 2014. http://rodriguesia-seer.jbrj.gov.br/index.php/rodriguesia/article/view/ ID\%20788/pdf_128

RAMOS, M. B. P.; FERRAZ, I. D. K. Estudos morfológicos de frutos, sementes e plântulas de Enterolobium schomburgkii Benth. (LeguminosaeMimosoideae). Revista Brasileira de Botânica, v.31, n.2, p.227-235, 2008. http://www.scielo.br/pdf/rbb/v31n2/v31n2a05.pdf.

RECORD, S. J.; HESS, R. W. Timbers of the New World. Yale Univ. Press, New Haven. 1943. 640p.

REGO, S. S.; COSMO, N. L.; GOGOSZ, A. M.; KUNIYOSHI, Y. S.; NOGUEIRA, A. C. Caracterização morfológica e germinação de sementes de Curitiba prismática (D. Legrand) Salywon \& Landrum. Revista Brasileira de Sementes, v.33, n.4, p.616-625, 2011. http://www.scielo.br/pdf/rbs/v33n4/03.pdf

RIBEIRO, J. W. F.; OLIVEIRA, A. K. M.; RODRIGUES, A. P. D. C.; RONDON, E. V. Germination and morphology of seeds and seedlings of Parkia gigantocarpa Fabaceae: Mimosoidae. Floresta, v.45, n.2, p.303-314, 2015. http://ojs.c3sl.ufpr.br/ojs/index.php/floresta/article/view/34504/25608.

RIZZINI, C. T. Árvores e madeiras úteis do Brasil: manual de dendrologia brasileira. 295p. 1971.

RIZZINI, C. T. Sistematização terminológica da folha. Rodriguésia, v.29 n. 42, p.103-25, 1977.

RODRIGUES, R. S. Morfologia de plântulas de Ateleia guaraya (Leguminosae, Papilionoideae). Boletim do Museu Integrado de Roraima, v.7, n.2, p.64-68. 2013. https://www.researchgate.net/profile/ Rodrigo_Rodrigues 12/publication/268217532_Morfologia_de plntulas_de_Ateleia_guaraya_\%28Leguminosae_Papilionoideae $\overline{\%} 29 /$ links $/ 54654 \mathrm{~b} 850 \mathrm{cf} 25 \mathrm{~b} 85 \mathrm{~d} 17 \mathrm{~d} 288 \mathrm{~b}$.pdf

RODRIGUES, R. S.; FEITOZA, G. V.; FLORES, A. S. Taxonomic relevance of seed and seedling morphology in two Amazonian species of Entada (Leguminosae). Acta Amazônica, v. 44, n.1,p. 19- 24, 2014. http://www. scielo.br/pdf/aa/v44n1/03.pdf

RODRIGUES, R. S.; HIRT, A. P. M.; FLORES, A. S. Morfologia de plântulas das espécies de Rhynchosia (Leguminosae, Papilionoideae) de Roraima, Brasil. Acta Botanica Brasilica, v.26, n.3, p. 585-592, 2012. http://www. scielo.br/pdf/abb/v26n3/v26n3a08.pdf. 
SILVA, B. M. S.; SILVA, C. O.; MÔRO, F. V.; VIEIRA, R. D. Morphoanatomy of fruit, seed and seedling of Ormosia paraensis Ducke. Journal of Seed Science, v.37, n.4, p.192-198, 2015. http://www.scielo.br/ pdf/jss/v37n4/2317-1537-jss-37-04-00192.pdf

SILVA, K. B.; ALVES, E. U.; BRUNO, R. L. A.; MATOS, V. P.; GONÇALVES, E. P. Morfologia de frutos, sementes, plântulas e plantas de Erythrina velutina Willd. leguminoseae - papilionideae. Revista Brasileira de Sementes, v.30, n.3, p.104-114, 2008. http://www.scielo.br/pdf/rbs/ v30n3/14.pdf

SILVA, A. C.; SANTOS, J. L. D’ARÊDE, L. O.; MORAIS, O. M.;COSTA, E. M.; SILVA, E. A. A. Caracterização biométrica e superação de dormência em sementes de Chloroleucon foliolosum (Benth.) G. P. Lewis. Agrária-Revista Brasileira de Ciências Agrárias, v. 09, n. 4, p. 577-582, 2014. http://agraria.pro.br/siste$\mathrm{ma} /$ index.php?journal $=$ agraria\&page $=$ article \&op=view\&path $\% 5 \mathrm{~B} \% 5 \mathrm{D}=$ agraria_v9i4a4586\&path\%5B $\% 5 \mathrm{D}=1712$
SOUZA, L.A. Morfologia e anatomia vegetal: célula, tecidos, órgãos e plântula. Ponta Grossa: UEPG. 2003. 259 p.

TAKHTAJAN, A. Floweing plants: origein and dispersal. Washington, Smithsonian Institute Press x, 1969. 310 p. 